\title{
SPILLOVERS ACROSS HOUSE PRICE CONVERGENCE CLUBS: EVIDENCE FROM THE POLISH HOUSING MARKET ${ }^{1}$
}

\author{
Mateusz Tomal \\ Department of Real Estate and Investment Economics \\ Cracow University of Economics \\ e-mail: tomalm@uek.krakow.pl
}

\begin{abstract}
The aim of this study is to assess whether significant spillovers exist among house price convergence clubs in the Polish housing market. This paper is a continuation of my previous research on house price convergence in Poland. In order to achieve the defined goal, VAR modelling was used. Based on the results of the VAR model, impulse response functions (IRFs) and the Spillover Index were calculated. The obtained results indicate that spillovers in the Polish housing market are strong. The relationships are observed both inside the primary and secondary markets and between them. In particular, a very powerful influence is exerted from a club of cities from the primary market, consisting of Cracow, Warsaw, Gdańsk, Poznań, Rzeszów and Wrocław, on the remaining identified house price convergence clubs.
\end{abstract}

Key words: house price convergence, impulse response function, spillover index, VAR model, ripple effect.

JEL Classification: C10, R31, R32.

Citation: Tomal, M. (2020). Spillovers across house price convergence clubs: evidence from the polish housing market. Real Estate Management and Valuation, 28(2), 13-20.

DOI: https://doi.org/10.1515/remav-2020-0012.

\section{Introduction}

In my previous study (Tomal, 2019), I identified the existence of house price convergence clubs in the Polish housing market. In particular, I used data from Polish provincial capitals concerning the average prices of flats both in the primary and secondary markets in the years 2006-2018. In order to assess the possible occurrence of house price convergence among the cities in question, I based my research on the method outlined by Phillips and Sul (2007). The results rejected the prospect of an equilibirum among the prices in the long-term. Notwithstanding, three convergence clubs have been recognised both in the primary and secondary markets. A summary of the results of this study is presented in Table 1. Despite the fact that the cities do not share a common house price trend in the long-term, there is a chance that significant spillovers exist across the clubs. In other words, I want to study whether relationships might exist between these clubs in the Polish housing market. These relationships might be evident inside the primary and secondary markets or across them.

The main results of this research show that spillovers across the identified house price convergence clubs are meaningful. The impact of the clubs from the primary market, however, is much stronger than that of clubs from the secondary market. The most influential is club 1 from the primary market, which affects almost all examined housing markets. On the contrary, the least influential is club 3 from the secondary market (according to values of net contributions). It should be noted that the

\footnotetext{
1 The publication is financed by a subsidy granted to the Cracow University of Economics.
} 
results of the research also indicated that spillovers exist both inside and across the primary and secondary markets.

The rest of the paper is organised as follows: section 2 describes the current empirical research on spillovers across house price convergence clubs. In section 3, I present the data and methods, which I use to investigate spillovers across the clubs. Section 4 contains the empirical results of the study, as well as a discussion. In the last section, I present the conclusions of the work.

Table 1

Classification of convergence clubs

\begin{tabular}{lll}
\hline & Club & Member cities \\
\hline \multirow{2}{*}{$\begin{array}{l}\text { The } \\
\text { primary } \\
\text { market }\end{array}$} & {$[1]$} & Gdańsk, Cracow, Poznań, Rzeszów, Warsaw, Wrocław \\
\cline { 2 - 3 } & {$[2]$} & Bydgoszcz, Katowice, Lublin, Olsztyn, Opole, Szczecin, Łódź \\
\cline { 2 - 3 } $\begin{array}{l}\text { The } \\
\text { secondary } \\
\text { market }\end{array}$ & \begin{tabular}{l}
{$[1]$} \\
\cline { 2 - 3 }
\end{tabular} & Białystok, Kielce, Zielona Góra \\
\cline { 2 - 3 } & {$[3]$} & Lublin, Opole, Poznań, Rzeszów, Wrocław \\
\hline
\end{tabular}

Source: own study.

\section{Literature review - spillovers across house price convergence clubs ${ }^{2}$}

Studies concerning spillovers across house price convergence clubs are extremely rare; there has been only a single study dealing with this. It was conducted by Montagnoli and Nagayasu (2015) and concerns house price convergence clubs in the United Kingdom. The authors of this study discovered that significant spillovers exist across the identified convergence clubs. More specifically, the influence of house prices in London on house prices in other regions is very strong. To the best of my knowledge, this is the only research to date testing spillovers across house price convergence clubs. Another study exploring house price convergence and spillovers was carried out by Gong et al. (2016). The authors checked whether spillovers existed across ten housing markets in China. The results indicated that a spillover effect is evident among selected housing markets. Moreover, the study showed that shocks in a given city first spread to its most immediate neighbouring cities. In this study, however, the potential existence of convergence clubs was not checked. It should be noted that the above mentioned studies are the only dealing jointly with issues of house price convergence and spillovers. Other studies in this area tested price convergence in the housing market as well, but did not take into account any shocks to prices (Greenaway-Mcgrevy et al. 2017; Chow et al. 2016). In these studies, the authors tested shocks given to socio-economic variables and their impact on house prices for selected cities in China, Australia and New Zealand.

In summary, it should be stressed that there is no empirical study on the subject, which takes into consideration the Polish housing market, resulting in a gap in the literature.

\section{Data and Methods}

In order to investigate spillovers across house price convergence clubs in this study, I use quarterly data from 2006:Q3 to 2018:Q3 on average flat prices per $\mathrm{m}^{2}$ in Polish provincial capitals both in the primary and secondary markets. The data originate from the National Bank of Poland. Additional information, presenting the classification of convergence clubs, is contained in Table 1.

The methodology of this article includes the following steps:

- Step 1. Calculating weighted average house prices in each identified convergence club on the basis of house prices from cities within a given club. The calculation uses the population of a given city as a weight to take into account the size of the housing market.

- Step 2. Seasonal adjustment of the time series calculated in Step 1.

- Step 3. Calculating time series representing annual house price rates of change in each identified convergence club.

\footnotetext{
2 Extensive literature review on house price convergence is presented in my previous article (TOMAL 2019).
} 
- Step 4. Testing the stationarity of each time series defined in Step 3 using the ADF test (Dickey \& Fuller 1979; 1981).

- Step 5. Selecting the lag order for a VAR model using the Schwarz (1978) criterion.

- Step 6. Assessing estimates of the VAR model.

- Step 7. Calculating impulse response functions based on the estimates of the VAR model.

- Step 8. Calculating the spillover index and related measures based on the VAR model.

Six variable are used in this article (six convergence clubs have been identified). On this basis and the Schwarz (1978) criterion ${ }^{3}$, the VAR model takes the form (Toyoshima \& Hamori 2018; Marona \& Bieniek 2013):

$$
P_{t}=P_{0}+A_{1} P_{t-1}+\varepsilon_{t}
$$

where $P_{0}$ denotes a vector of constants, $P_{t}=\left(C 1 P_{t}, C 2 P_{t}, C 3 P_{t}, C 1 S_{t}, C 2 S_{t}, C 3 S_{t}\right)^{\prime}$ is a vector of house price rates of change variables at time $t, C 1 P_{t}, \ldots, C 3 S_{t}$ are convergence club time series $(C$ denotes a club, $1, \ldots, 3$ is the number of a club, $P$ and $S$ represent either the primary or the secondary market), $A_{i}$ is a matrix of autoregressive parameters, $P_{t-1}$ is a vector of lagged house price rates of change variables, $\varepsilon_{t}$ is a vector of error terms. The interpretation of a VAR model may be performed on the basis of the assessment of the significance of the entire estimated model. Additionally, the results of a VAR estimation are usually interpreted by the Granger causality test. Much more interesting are the concepts of impulse response function and forecast error variance decomposition. In order to understand the concept of the impulse response function, it is necessary to present a VAR model in an infinite moving-average form (only if the VAR model is stable), which is as follows:

$$
P_{t}=\mu+\sum_{i=0}^{\infty} \Phi_{i} \varepsilon_{t-i}
$$

where $\mu$ is the time-invariant mean of the process, $\Phi_{i}$ are matrices of parameters. The coefficients $\Phi_{i}$ are also known as simple impulse response functions (IRFs) at horizon $i$ (Lütkepohl 1990). This means that the values of $P_{t}$ are determined by a combination of shocks entering the system. On this basis, one can conclude that the future values of $P_{t}$ result from past shocks. Another way to interpret the estimates of a VAR model is the Spillover Index concept outlined by Diebold and Yilmaz (2009; 2012), which is based on variance decomposition of forecast errors. In order to explain this method, the Spillover Index should be first decomposed into the Spillover Table (Table 2).

Table 2

The concept of the Spillover Table

\begin{tabular}{llllllll}
\hline Fo & From & & & & & & \\
\hline C1P & C1P & C2P & C3P & C1S & C2S & C3S & $\begin{array}{l}\text { Contribution } \\
\text { from others }\end{array}$ \\
\hline C2P & $s_{11}$ & $s_{12}$ & $s_{13}$ & $s_{14}$ & $s_{15}$ & $s_{16}$ & $\sum_{j=1}^{6} s_{1 j}-s_{11}$ \\
\hline C3P & $s_{21}$ & $s_{22}$ & $s_{23}$ & $s_{24}$ & $s_{25}$ & $s_{26}$ & $\sum_{j=1}^{6} s_{2 j}-s_{22}$ \\
\hline C1S & $s_{31}$ & $s_{32}$ & $s_{33}$ & $s_{34}$ & $s_{35}$ & $s_{36}$ & $\sum_{j=1}^{6} s_{3 j}-s_{33}$ \\
\hline C2S & $s_{41}$ & $s_{42}$ & $s_{43}$ & $s_{44}$ & $s_{45}$ & $s_{46}$ & $\sum_{j=1}^{6} s_{4 j}-s_{44}$ \\
\hline C3S & $s_{51}$ & $s_{52}$ & $s_{53}$ & $s_{54}$ & $s_{55}$ & $s_{56}$ & $\sum_{j=1}^{6} s_{5 j}-s_{55}$ \\
\hline $\begin{array}{l}\text { Contribution to } \\
\text { others }\end{array}$ & $s_{61}$ & $\sum_{62}^{6} s_{i 1}-$ & $S_{63}^{6} s_{i 2}-\sum_{i=1}^{6} s_{i 3}-\sum_{i=1}^{6} s_{i 4}-\sum_{i=1}^{6} s_{i 5}-\sum_{i=1}^{6} s_{i 6}-$ & \\
\hline & $s_{11}$ & $s_{22}$ & $s_{33}$ & $s_{44}$ & $s_{55}$ & $s_{66}$ & \\
\hline
\end{tabular}

Notes: symbols C1P, ..., C3S are the same as in equation 1. Source: own study.

In the above table, the $i j$ cell is the estimated contribution to the forecast error variance of club $i$ originating from innovations to club $j$. In other words, for example, innovations in club C2P returns

\footnotetext{
${ }^{3}$ The Schwarz (1978) criterion indicated that the best model for the data should have a lag order equal to 1 or 2 (the criterion estimates are almost the same). Finally, a lag order equal to 1 was chosen because in this case the model passes the residual normality test better.
} 
are responsible for $s_{32} \%$ of the error variance in forecasting house price rates of change in club C3P. Moreover, based on Table 2, it is possible to calculate the Spillover Index by dividing the sum of the contributions from others by the sum of the contributions to others including own. This measure informs us on the percentage of spillovers in the forecast error variance of rates of change. Furthermore, based on Table 2, one can calculate the so-called net contribution, which is expressed in the following form:

$$
\text { net contribution }{ }_{j}=\text { contribution to others } . j-\text { contribution from others }_{i} \text {. }
$$

\section{Empirical results}

\subsection{VAR model estimates}

Before estimating a VAR model, stationarity of each variable was checked using the ADF test. The results of this test indicated that all variables are stationary, which is also confirmed by Figure 1.
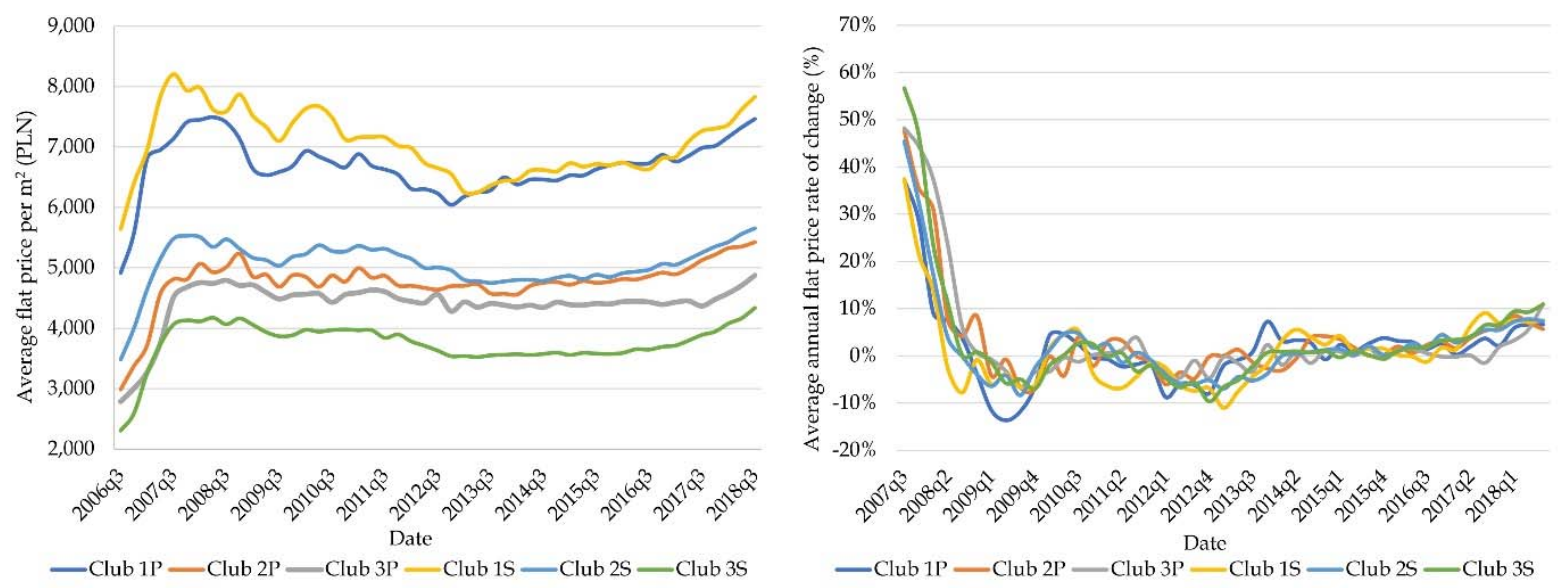

Fig. 1. Levels of house prices and their rates of change in the clubs. Source: own study.

The following step in the research is to calculate a VAR model. As already explained, a VAR model with a lag order equal to 1 was chosen. The estimates of the model are contained in Table 3.

Table 3

VAR model estimates

\begin{tabular}{lllllll}
\hline & Equation & & & & & \\
\hline Variable & $C 1 P_{t}$ & $C 2 P_{t}$ & $C 3 P_{t}$ & $C 1 S_{t}$ & $C 2 S_{t}$ & $C 3 S_{t}$ \\
\hline$C 1 P_{t-1}$ & $0.43^{* * *}$ & -0.01 & -0.15 & $0.68^{* * *}$ & $0.29^{* * *}$ & $0.44^{* * *}$ \\
\hline$C 2 P_{t-1}$ & 0.10 & -0.07 & $0.36^{* * *}$ & -0.07 & -0.01 & $0.30^{* * *}$ \\
\hline$C 3 P_{t-1}$ & -0.09 & -0.18 & -0.14 & 0.03 & $-0.15^{*}$ & $-0.33^{* * *}$ \\
\hline$C 1 S_{t-1}$ & 0.11 & $-0.58^{* * *}$ & -0.11 & 0.13 & -0.08 & 0.02 \\
\hline$C 2 S_{t-1}$ & -0.25 & $1.03^{* * *}$ & -0.05 & 0.03 & 0.09 & $0.46^{* * *}$ \\
\hline$C 3 S_{t-1}$ & 0.25 & 0.39 & $0.71^{* * *}$ & 0.04 & $0.55^{* * *}$ & 0.19 \\
\hline$R^{2}$ & 0.83 & 0.88 & 0.96 & 0.85 & 0.94 & 0.96 \\
\hline F-test p-value & 0.00 & 0.00 & 0.00 & 0.00 & 0.00 & 0.00 \\
\hline
\end{tabular}

Notes: ${ }^{* * *}$ One percent level of significance. ${ }^{* *}$ Five percent level of significance. ${ }^{*}$ Ten percent level of significance. The Doornik-Hansen $(\mathrm{p}$-value $=0.82)$ test proves that the residuals in the model have a normal distribution. The estimation was carried out with HAC standard errors and two control variables describing unemployment rate and population. The latter variables are not lagged and their annual rates of change were used in the model. Source: own study. 
Based on the above table, it should be stressed that all equations are significant, because F-test p-values are lower than 0.05 in each case. Moreover, the $R^{2}$ values indicate that the goodness of fit of the model is quite high. Furthermore, estimates in Table 3 denote that the most influential club is club 1 from the primary market. Past house price rates of change from this club significantly affect present house price rates of change in four clubs (including own). These results are not surprising because a very high real estate turnout is observed in club 1 from the primary market. One may argue that this market shapes almost the entire housing market in Poland.

\subsection{IRFs estimates}

In order to explore spillovers across the identified convergence clubs, IRFs were used. The best way to interpret IRFs is to present them in the form of graphs (Figure 2).
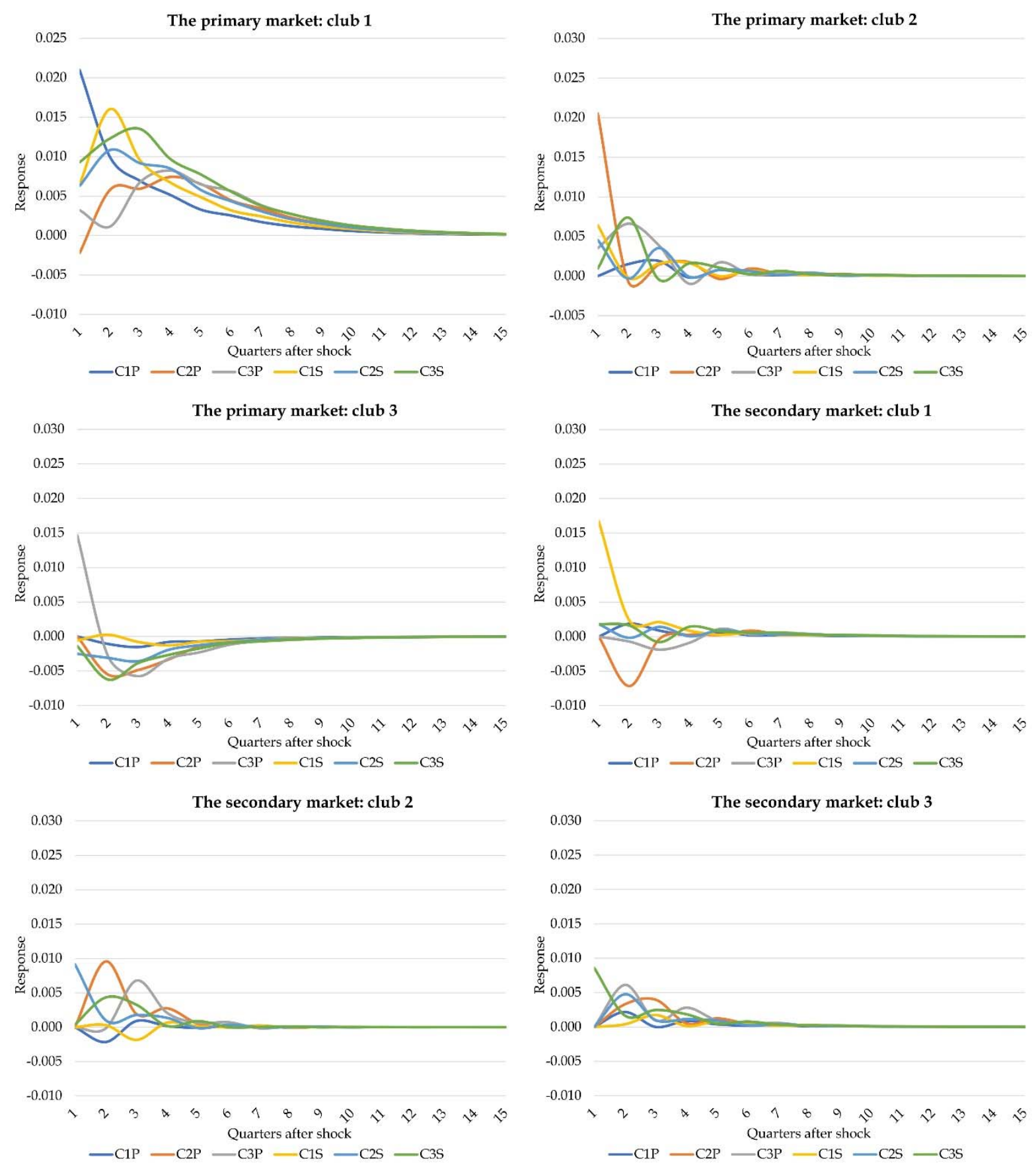

Fig. 2. IRFs for house price rates of change. Source: own study. 
Figure 2 delivers very interesting findings. Firstly, in each case, the effect of a shock to a given club dissipates after about 8-10 quarters. The most intensive effects on house price rates of change in the clubs are caused by a shock given to club 1 from the primary market. In particular, a one standard deviation shock to house price rates of change in club 1 from the primary market causes a significant increase in house price rates of change in all other clubs for about 5-6 quarters. The peak of this influence is visible 2-3 quarters after the shock. On this basis, one can conclude that a significant ripple effect from club 1 in the primary market to other convergence clubs is at play.

Moreover, it should be noted that the case of club 1 from the primary market is the only one where a shock generates an increase in house price rates of change in all convergence clubs for the entire forecast horizon. On the contrary, shocks to club 3 both in the primary and secondary markets, as well as to club 1 in the secondary market, barely have a discernible impact on house price returns.

\subsection{Spillover index estimates}

In order to thoroughly analyse spillovers across the identified convergence clubs, the Spillover Index and related measures have been calculated. The Spillover Table for 4-quarter forecast is presented in Table 4 . On the basis of the results, one can conclude that $56.23 \%$ of the forecast error variance of house price rates of change can be explained by spillovers.

Moreover, the results in Table 4 confirm the hypothesis of the ripple effect from C1P house price rates of change to other convergence clubs. For example, innovations to the abovementioned club are responsible for $67.67 \%$ of the error variance in forecasting C3S returns but only $22.24 \%$ of the error variance in forecasting C3P returns. Generally, club 1 from the primary market has very strong impact on the whole of the secondary market.

Furthermore, based on Table 4, one can see that there are very different results of measures concerning total spillover contribution to and from others. In particular, the biggest contribution from others is noted for club 3 in the secondary market. Essentially, the total estimated contribution to the forecast error variance of this club's house price rates of change is equal to $88.63 \%$. Conversely, innovations to this clubs' returns are collectively responsible for only $17.81 \%$ of the forecast error variances in all other clubs. Therefore, a net contribution equal to $-70.82 \%$ for the 4 -quarter forecast is noted for this club. A positive value of net contribution is observable only for club 1 in the primary market.

Values of the above-mentioned measures for the whole of the analysed forecast horizon are presented in Figure 3.

Table 4

The Spillover Table for 4-quarter forecast

\begin{tabular}{|c|c|c|c|c|c|c|c|}
\hline & From & & & & & & \\
\hline To & $\mathrm{C} 1 \mathrm{P}$ & $\mathrm{C} 2 \mathrm{P}$ & $\mathrm{C} 3 \mathrm{P}$ & C1S & $\mathrm{C} 2 \mathrm{~S}$ & C3S & $\begin{array}{l}\text { Contribution } \\
\text { from others }\end{array}$ \\
\hline C1P & 96.02 & 0.94 & 0.65 & 0.66 & 0.86 & 0.86 & 3.98 \\
\hline $\mathrm{C} 2 \mathrm{P}$ & 16.11 & 53.20 & 8.09 & 6.43 & 12.81 & 3.36 & 46.80 \\
\hline C3P & 22.24 & 12.85 & 46.98 & 0.85 & 8.91 & 8.17 & 53.02 \\
\hline C1S & 55.65 & 5.97 & 0.35 & 37.12 & 0.50 & 0.41 & 62.88 \\
\hline $\mathrm{C} 2 \mathrm{~S}$ & 62.71 & 6.73 & 6.54 & 1.05 & 17.95 & 5.01 & 82.05 \\
\hline C3S & 67.67 & 7.68 & 8.26 & 1.13 & 3.89 & 11.37 & 88.63 \\
\hline $\begin{array}{l}\text { Contribution } \\
\text { to others }\end{array}$ & 224.36 & 34.18 & 23.90 & 10.12 & 26.99 & 17.81 & \multirow{3}{*}{$\begin{array}{l}\text { Spillover } \\
\text { index }=56.23\end{array}$} \\
\hline $\begin{array}{l}\text { Including } \\
\text { own }\end{array}$ & 320.38 & 87.38 & 70.88 & 47.25 & 44.94 & 29.18 & \\
\hline $\begin{array}{l}\text { Net } \\
\text { contribution }\end{array}$ & 220.38 & -12.62 & -29.12 & -52.75 & -55.06 & -70.82 & \\
\hline
\end{tabular}

Notes: symbols C1P,..., C3S are the same as in equation 1 . Source: own study. 

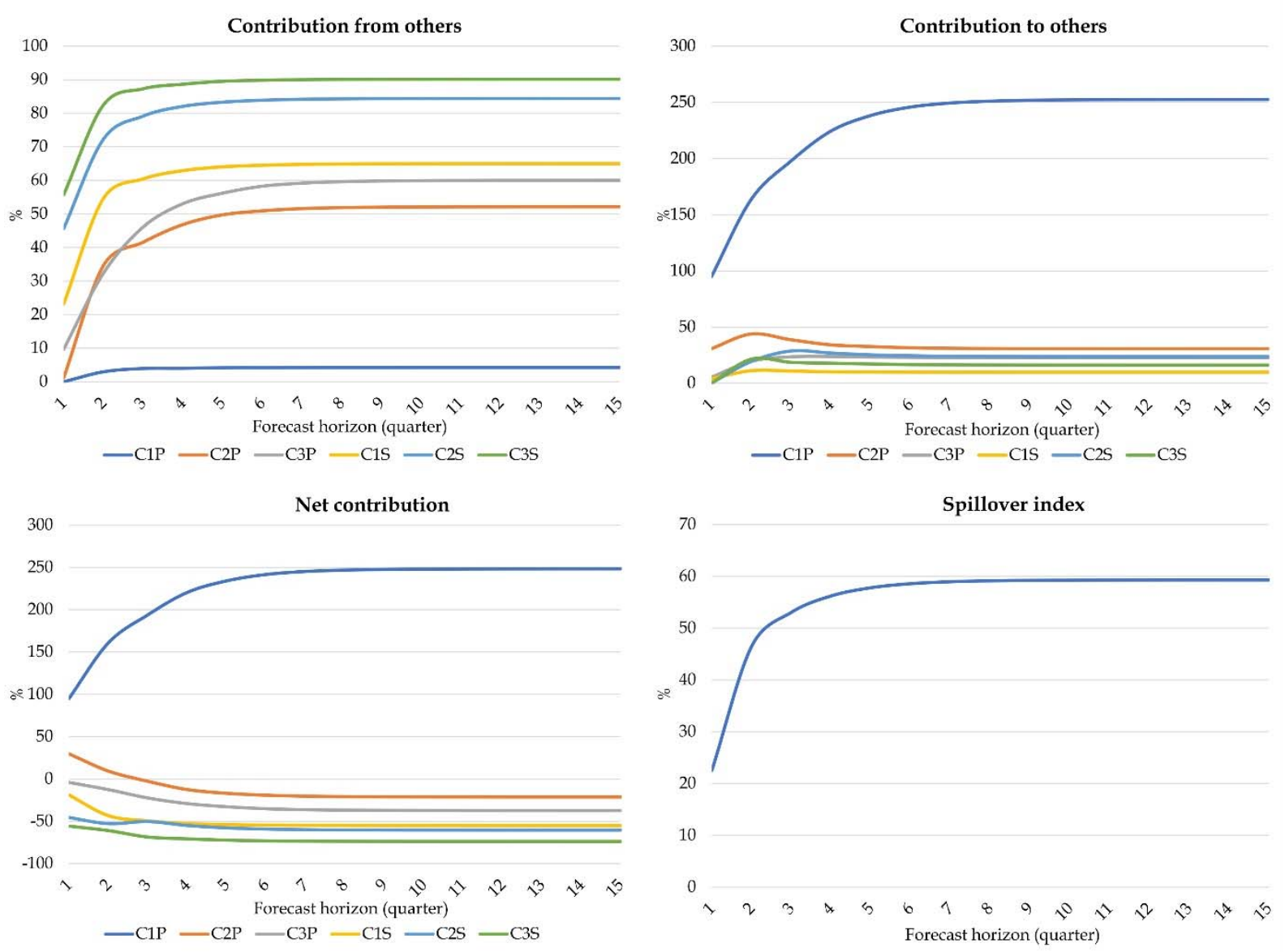

Fig. 3. The Spillover Index and related measures for house price rates of change. Source: own study.

\section{Conclusions}

The conducted research allowed the following conclusions to be formulated:

- significant spillovers exist across the identified convergence clubs,

- the most influential is club 1 from the primary market,

- clubs in the primary market are much more influential than clubs in the secondary market,

- there is a ripple effect from club 1 in the primary market to other convergence clubs, which means that the local real estate markets in the biggest cities of Poland, like Cracow or Warsaw, shape the whole of the housing market in the country.

According to the author's best knowledge, this research is the first carried out for the housing market in Poland, which accounts for the study's significant contribution to this research area.

\section{References}

Phillips, P. C., \& Sul, D. (2007). Transition modelling and econometric convergence tests. Econometrica, 75(6), 1771-1855. https:// doi.org/10.1111/j.1468-0262.2007.00811.x

Chow W.W., Fung M.K., Cheng A.C.S, 2016, Convergence and spillover of house prices in Chinese cities. Applied Economics, no. 48 (51), 4922-4941. https:// doi.org/10.1080/00036846.2016.1167829

Montagnoli A., Nagayasu J., 2015, UK house price convergence clubs and spillovers. Journal of Housing Economics, no. 30 (C), 50-58. https://doi.org/10.1016/i.jhe.2015.10.003

Narodowy Bank Polski. 15.01.2019 (the National Bank of Poland, 15.01.2019). Online: https://www.nbp.pl/home.aspx?f=/publikacje/rynek_nieruchomosci/index2.html

Gong, Y., Hu, J., \& Boelhouwer, P. J. (2016). Spatial interrelations of Chinese housing markets: Spatial causality, convergence and diffusion. Regional Science and Urban Economics, 59, 103-117. https://doi.org/10.1016/j.regsciurbeco.2016.06.003

Greenaway-Mcgrevy R., Grimes A., \& Holmes M. (2018). Two countries, sixteen cities, five thousand kilometres: How many housing markets? Papers in Regional Science, no. 98 (1), 353-370. https://doi.org/10.29310/wp 
Tomal, M., 2019, House price convergence on the primary and secondary markets: Evidence from Polish provincial capitals. Real Estate Management and Valuation, no. 27 (4), 62-73. https://doi.org/10.2478/remav-2019-0036

Schwarz, G.E., 1978, Estimating the dimension of a model. Annals of Statistics, no. 6 (2), 461-464. https://doi.org/10.1214/aos/1176344136

Lütkepohl, H., Asymptotic Distributions of Impulse Response Functions and Forecast Error Variance Decompositions of Vector Autoregressive Models. The Review of Economics and Statistics, no. 72 (1), 116-125. https:// doi.org/10.2307/2109746

Diebold, F.X., \& Yilmaz, K. (2009). Measuring financial asset return and volatility spillovers, with application to global equity markets, The Economic Journal, no. 119 (534), 158-171.

Diebold, F. X., \& Yilmaz, K. (2012). Better to give than to receive: Predictive directional measurement of volatility spillovers. International Journal of Forecasting, 28(1), 57-66. https:// doi.org/10.1016/j.ijforecast.2011.02.006

Toyoshima Y., \& Hamori S. 2018. Measuring the time-frequency dynamics of return and volatility connectedness in global crude oil markets. Energies, no. 11(11), 1-18. https://doi.org/10.3390/en11112893

Marona B., \& Bieniek A. (2013). Wykorzystanie modelu VECM do analizy wpływu bezpośrednich inwestycji zagranicznych na gospodarkę Polski w latach 1996-2010 (The analysis of the influence of foreign direct investment on polish economy in 1996-2010 using VECM methodology), Acta Universitatis Nicolai Copernici. Ekonomia (Acta Universitatis Nicolai Copernici. Economics), 44 (2), 333350.

Dickey D.A., \& Fuller W.A. (1979). Distribution of the estimators for autoregressive time series with a unit root. Journal of the American Statistical Association, 366 (74), 427-31.

Dickey D.A., \& Fuller W.A. (1981). Likelihood ratio statistics for autoregressive time series with a unit root. Econometrica, 49(4), 057-72. https://doi.org/10.2307/1912517 